\title{
A Subregional Analysis of Universities' Contribution to Economic and Innovation Performance
}

\author{
Zoltán Bajmócy • Miklós Lukovics • Zsófia Vas
}

Received: 16 September 2009/Accepted: 18 January 2010/Published online: 30 March 2010

(C) Springer-Verlag 2010

\begin{abstract}
In recent years several regions have created development strategies to strengthen the regional economic and innovation contribution of universities. Still, it is not at all obvious whether universities' significant regional contribution is a rule or rather an exception, especially in transition and less developed areas. Present paper addresses three crucial fields that seem to be problematic in the literature. First, we analyze universities' regional contribution in a transition economy, namely in Hungary. Second we attempt to capture territorial innovation performance by applying an innovation system based approach. Third, we carry out a nationwide analysis on a subregional level. We conclude that regional contributions of Hungarian higher education institutions are modest, way too forceless to catalyze the local economy.
\end{abstract}

Keywords Universities' regional contribution · Innovation performance · Transition economy $\cdot$ Hungary

JEL Classification $\mathrm{O} 18 \cdot \mathrm{O} 30 \cdot \mathrm{O} 43 \cdot \mathrm{R} 11$

\section{Introduction}

The role of universities in systems of innovation and their contribution to economic development are widely approached research issues. Nowadays industries are

\footnotetext{
Z. Bajmócy $(\bowtie) \cdot$ M. Lukovics · Z. Vas

Faculty of Economics and Business Administration, University of Szeged, Szeged, Hungary e-mail: bajmocyz@eco.u-szeged.hu

M. Lukovics

e-mail: miki@eco.u-szeged.hu

Z. Vas

e-mail: vas.zsofia@eco.u-szeged.hu
} 
increasingly tied to universities, since they provide both people trained in the relevant fields, and research findings which enable technology to advance further (Nelson 1995). The "co-evolutionary" knowledge production between the academic and business sphere is widely recognized in the literature of innovation systems (Lundval 1992; Nelson 1993) and especially in the triple helix concepts (Etzkowitz et al. 2000; Etzkowitz and Leydesdorff 2000).

The literature of innovation systems has revealed that not only is the presence of the universities important, but also the character and intensity of the relations between universities and other participants of the system. A large body of literature deals with the mechanisms through which the academic knowledge production affects the corporate innovation performance (Etzkowitz and Leydesdorff 2000; Inzelt 2004; Bercovitz and Feldman 2006), the spatiality of these mechanisms (Feldman 1994; Varga 1998; Morgan 2002; Goldstein and Renault 2004), and the transformation within the academic sphere that enables the operation of these mechanisms (Etzkowitz et al. 2000; Goldfarb and Henrekson 2003; Clarysse et al. 2005; Antonelli 2008).

Regional science has made a very important contribution to this issue. They have shown that the flow of knowledge from universities to industries is spatially bounded (Audretsch and Feldman 1996; Anselin et al. 1997; Varga 1998; Autant-Bernard 2001). Since economic actors cannot benefit equally from university "spillovers" in different places, the spatial distribution of academic knowledge production becomes a significant factor of economic development (Varga 2009).

Although several attempts have been made to discover whether universities' economic contribution is a rule or rather an exception, certain issues still generate lively debates. First, the empirical evidence is constrained to a few countries. The evidence hardly regard less developed and transition economies, however in many of these countries a number of central and local development strategies are based on the expected economic development effects of universities. Second, the way of capturing innovation in the econometric models of university knowledge spillovers is often criticized. Third, it is very difficult to carry out nationwide (or even broader) analyses on a low level of territorial aggregation, therefore subregional analyses are almost totally absent in the literature.

In present paper we attempt to focus on these three crucial fields. We analyze whether universities' contribution to territorial innovation and economic performance can be proved in a transition economy, namely in Hungary. We use an innovation system based approach to capture territorial innovation performance, to measure universities' contribution and we carry out a countrywide analysis on a subregional level.

In "Regional economic contribution of universities" we provide a brief review of the literature of universities' regional contribution and draw attention to certain problematic fields. Section "Methodology" provides an overview of the methodology of our analysis, which is based on Hungarian subregional (LAU-1) database. In the subsequent section, we show the results of the analysis and we draw our conclusions finally. 


\section{Regional economic contribution of universities}

Although the external relations of the universities are to a great extent globally tied, a certain part of university-industry relations have strong spatial characteristics. This is due to the fact that the technology transfer process is embedded into the contexts of local routines and in many cases requires regular personal interactions (Bercovitz and Feldman 2006). Hence local embeddedness gains an important role, which sheds light on the importance of the analysis of the local and regional innovation systems (Asheim and Coenen 2005). Also policy competences and institutions that influence university-industry relations are in many cases bound to subnational territories (Cooke 2004). On the top of this, knowledge externalities (spillovers) that play a vital role in the innovation process have spatial characteristics, they are mostly local, thus the spatial distribution of the participants matters (Varga 2009).

Therefore the spatial characteristics of universities' effects have an abundant literature. These potential effects can be divided into two main groups: the inputside or income effects, and the output-side or knowledge-effects, which covers the scientific, technical and economic knowledge streaming from the academic to the business sphere (Armstrong and Taylor 2000; Morgan 2002; Varga 2004). Income effects basically derive from the local spending of the university, its students and staff. Although they may have a significant role in certain areas, they are unable to catalyze the local economy, ${ }^{1}$ and static in nature. Conversely, knowledge-effects are able to induce dynamic local development: they can serve as a basis of the local innovation potential, and thus eventually the improvement of economic performance and the rise of local incomes.

In connection with the knowledge-effects the most intensely researched issue is probably the analysis of the local spillovers deriving from the spatial concentration of R\&D activities. A number of empirical studies proved a significant and positive relation between university R\&D and the efficiency of private innovation activities in case of spatial proximity (Audretsch and Feldman 1996; Anselin et al. 1997; Varga 1998; Autant-Bernard 2001). With the increase of the distance the relation becomes insignificant. These econometric analyses, which are based on the knowledge-production function, provide important proof of the existence of academic knowledge spillovers and their local nature. However these studies are often criticized for the way they capture innovation capacity. They either use number of patents or a literature-based innovation measure that basically captures R\&D-based high-tech product innovation activity. So they exclude a whole range of potential innovations that have vital importance especially in transition countries. The European Innovation Scoreboard (EIS 2008) shows for example that in Hungary 55\% of innovative firms do not conduct any R\&D. This proportion is also reinforced by Csizmadia et al. (2008) and Inzelt and Szerb (2003).

\footnotetext{
1 The ways of strengthening the income effects are, on the one hand, the increase of the number of students and the staff, on the other hand, the rise of the proportion of local spending. These face objective hindrances (e.g. public procurement rules do not allow the university to prioritize local buying). Therefore the strengthening of the income effects is not an objective of local economic development.
} 
Beside the knowledge externalities connected to the formalized R\&D results, there may be numerous other channels of universities' potential regional economic effects. In this respect the analysis of Goldstein and Renault (2004) based on American time series provides essential results. They generally proved that in the US the presence of research universities significantly affects the rise of regional incomes compared to national average, but only after $1986,{ }^{2}$ when-as a consequence of the Bayh-Dole Act-universities started to make serious efforts to strengthen their industrial relations.

While the above results provide strong supporting evidence about universities regional economic and innovation effects, they still leave a lot of questions open, and cannot be unambiguously exteriorized to transition economies.

First, in the transition countries the performance of the regional innovation systems is characteristically weak (Hollanders 2006) and in many cases heavily influenced by foreign affiliates (Lengyel and Cadil 2009). University-industry relations are far from being a real triple helix (Inzelt 2004), and the political actions aiming at the encouragement of university-related technology transfer have just begun being amplified. Furthermore, the effectiveness of university-related local economic development programmes can be questioned in many cases (Buzás 2003; Bajmócy 2006; Lengyel 2009).

Second, the literature of university knowledge spillovers implicitly equals territorial innovation capacity with the $R \& D$ based product (and possibly process) innovation performance of the private sector. However, the literature of innovation systems stresses that there is a whole range of factors influencing territorial innovation capacity (Nelson 1993; Lundvall et al. 2002; Edquist 2005). Measurement approaches rooted in this tradition use a complex set of indicators that are able to reflect the operation of the innovation system (EIS 2008; Arundel and Hollanders 2005; Hollanders 2006; Kanerva et al. 2006).

Third, a large part of universities' expected effects are markedly local. This infers that even the regional level may be too wide to capture certain processes or differences. At the same time the difficulties of data access usually prevents scholars from going beyond the level of regions. While methods remaining at a higher level of territorial aggregation provide greater opportunities for nationwide and international comparison and the use of more sophisticated data sets, they are unable to reflect to the subregional (local) characters of the examined phenomenon.

\section{Methodology}

The literature of universities' regional effects puts the knowledge-effects into the focus of the interest. In the present paper we also carry on with this tradition, since we attempt to analyse Hungarian higher education institutions' (HEIs) ability to boost their host region's economy.

For the purpose of our study we took the analysis of Goldstein and Renault (2004) as a starting point, but we carried out certain modifications on it. First, we

\footnotetext{
${ }^{2}$ Although the Bay-Dole Act was adopted in 1980, its effects became measurable only a few years later.
} 
widened the focus of analysis; beside the change in average wages we also examined the effects of HEIs on the complex innovation performance. Second, we carried out our analysis on local (LAU-1) level, which significantly influenced data availability. Third, we carried out our examinations in such a country, where the subregion of the capital (Budapest) concentrates a significant proportion of the population, gross value added (GVA) and research capacities. This inevitably had to be considered in the statistical analysis.

The examined period was 1998-2007, while the units of our analysis were the 168 Hungarian (LAU-1) subregions. ${ }^{3}$ Although the presently valid classification defines 174 subregions, the statistical data used by us could not be aggregated according to the new territorial classification in all cases. For the computations we used MS Excel and SPSS 15.0.

\section{Indicators used}

For analyzing the HEIs' regional effects, we used three set of indicators: the dependent variables (which indicate the potential forms of contribution), HEIrelated indicators and control variables (Table 1).

Two of the dependent variables are related to the innovation performance: the subregional summary innovation index (SRSI) and the knowledge-exploitation index (KEI). ${ }^{4}$ The latter two dependent variables refer to the change in the subregional economic performance and in the incomes of the inhabitants: the per capita gross value added (GVA) and the gross tax base per tax payer. Per capita GVA is analogous to per capita GDP in its content, ${ }^{5}$ while the gross tax base per tax payer captures the disposable incomes of the residents. ${ }^{6}$ The computation of the variables is analogous to the method of Goldstein and Renault (2004). We first calculated the values of the variables as a percentage of the national average for each subregion for 1998 and for 2007. The dependent variable is then calculated as a difference in the indexes for the given subregion between the two years. The positive value of the variable therefore refers to a growth rate exceeding the national average (catching-up or increasing the advantage).

Thus two of our dependent variables are based on the change of the indicator values, while two are cross-section data. But innovation performance refers to the speed of change in itself, so the introduction of the growth rate of the innovation indexes is unneeded.

The presence of HEIs is measured by five indicators. Two of them are dummy variables (present or not in the subregion), while three are measured on scale. The latter are indicators related to the basic functions of the universities: the number of scientists with $\mathrm{PhD}$ qualifications, the number of full-time students and the number

\footnotetext{
3 Defined by the Government Regulation 244/2003.

4 The computing method of the two indexes is outlined later in the chapter.

5 GDP is not available for LAU-1 subregions, thus GVA is used as a substitute.

${ }^{6}$ Goldstein and Renault (2004) used the wages as dependent variable, but in this case we also had to face the unavailability of the data in subregional level.
} 
Table 1 Indicators of the analysis

\begin{tabular}{|c|c|}
\hline Economic effects & Innovation effects \\
\hline \multicolumn{2}{|l|}{ Dependent } \\
\hline $\begin{array}{l}\text { Change in the gross personal tax base per tax payer } \\
\text { compared to national average (in } \% \text { points) }\end{array}$ & $\begin{array}{l}\text { Subregional Summary Innovation Index } \\
\text { (SRSI) }\end{array}$ \\
\hline $\begin{array}{l}\text { Change in the gross value added per capita compared } \\
\text { to national average (in } \% \text { points) }\end{array}$ & Knowledge Exploitation Index (KEI) \\
\hline \multicolumn{2}{|l|}{ HEI-related } \\
\hline Is there a HEI in the subregion? & Is there a HEI in the subregion? \\
\hline Is there a university in the subregion? & Is there a university in the subregion? \\
\hline Number of scientists with $\mathrm{PhD}$ per 10,000 inhabitants & $\begin{array}{l}\text { Number of scientists with } \mathrm{PhD} \text { per } 10,000 \\
\text { inhabitants }\end{array}$ \\
\hline $\begin{array}{l}\text { Number of full-time students in HEIs per } \\
1,000 \text { inhabitants }\end{array}$ & $\begin{array}{l}\text { Number of full-time students in HEIs per } \\
1,000 \text { inhabitants }\end{array}$ \\
\hline $\begin{array}{l}\text { High education in the fields of science, } \\
\text { engineering and informatics }\end{array}$ & $\begin{array}{l}\text { High education in the fields of science, } \\
\text { engineering and informatics }\end{array}$ \\
\hline \multicolumn{2}{|l|}{ Control } \\
\hline Number of employees & Number of employees \\
\hline Population of the centre of the subregion & Population of the centre of the subregion \\
\hline \multicolumn{2}{|l|}{$\begin{array}{l}\text { Percent employment in manufacturing and } \\
\text { construction }\end{array}$} \\
\hline \multicolumn{2}{|l|}{ Percent employment in services } \\
\hline Complex accessibility indicator & Complex accessibility indicator \\
\hline \multicolumn{2}{|l|}{ Percent of incomes generated by proprietorships } \\
\hline \multicolumn{2}{|l|}{ Number of patents per 10,000 inhabitants } \\
\hline \multicolumn{2}{|l|}{$\begin{array}{l}\text { Base-year level of gross personal tax-base } \\
\text { per tax payer }\end{array}$} \\
\hline Base-year level of gross value added per capita & \\
\hline
\end{tabular}

The source of data is TEIR (Hungarian Spatial Development Information System), Higher Education Statistical Database of the Ministry of Education and Culture and own computation in case of the SRSI and KEI. Indicators refer to 1998 and 2007, respectively, except for the complex accessibility indicator that was calculated only once in 2004

of degrees awarded in the fields of science, engineering and informatics. These variables refer to the base year (1998).

To capture the potential effects of HEIs the use of HEI-related indicators is not sufficient, since the difference between subregions with and without HEIs may be caused by many other influencing factors. Therefore in our analysis we applied control variables which are potentially able to explain a significant proportion of the dependent variable's variation.

The first group of the control variables tries to capture the agglomeration economies; they refer to the size of the subregion. Instead of using the overall population of the subregion, we decided to introduce the population of the centre of the subregion, which better indicates the size of the local concentration.

In order to map the economic structure of the subregions we used two variables: the relative weight of manufacturing and services in the employment. We indicated 
the accessibility of the subregion by the complex accessibility index ${ }^{7}$ of the Hungarian Central Statistics Office (HCSO 2004). Several empirical results prove the link between entrepreneurship and economic performance (Bosma and Harding 2006). We used two variables in this category: the percent of incomes generated by proprietorship and the number of patents per 10,000 inhabitants. In Hungary the number of private sector patents is not available for subregions, but in the period examined (basically due to regulatory causes) the patent activity of the academic sector is very low. We considered furthermore the base-year performance of the subregion to control the endowment effect.

In case of the analysis of the innovation effects we decreased the number of control variables, since part of them are taken into account as components of the subregional innovation performance.

The steps of the analysis

We carried out the analysis of HEIs' potential contribution in two basic steps. The differences regarding the innovation and economic performance of subregions with and without HEIs may derive from many factors. In the first step of our analysis we attempted to explain these potential differences by using our control variables.

We fitted linear regression models to all of the four dependent variables in order to test the explanatory power of the control variables. We used the "backward" method of the SPSS, so we gained such "base-models" where a relevant set of the control variables are included with the maximum possible overall explanatory power. Therefore the "base-models" indicate the explanatory power of the relevant control variables in case of all the dependent variables.

In the second step we attempted to unfold the extent of university contribution. We used here two methods. First, we analysed whether there is a correspondence between the dependent variables and the HEI-related indicators when controlling for the effects of the relevant set of control variables. We calculated here partial correlation results controlled for the independent variables of the base models.

Second, if we found significant correlation between a HEI-related indicator and a dependent variable, than we attempted to supplement our base-model with the given variable. Actually, we analyzed whether the HEI-related indicators provide extra explanatory power to our models.

We must mention here that both the HEI-related indicators and the control variables are strongly correlated to each other, thus our regression models are characterized by strong multicollinearity. Hence we only analyzed the overall explanatory power of the models (where the lack of multicollinearity is not a precondition), we could not and did not draw any conclusions on the partial effects of the given variables.

\footnotetext{
7 The index considers the time distance from the nearest county-centre $(40 \%)$, from the nearest subregion-centre (40\%), and the state of supply (20\%), which latter indicates the extent to which the residents are dependent on the services of the centres. Accessibility is calculated for all the municipalities and then, weighted by the population of the municipalities, the subregional index is calculated.
} 
Measuring the complex innovation performance of the subregions

One of the main focuses of our study is to unfold the correspondence between the presence of HEIs and the innovation performance of the host subregion. Innovation performance data on the Hungarian subregions were not available thus we had to carry out our own analysis to construct these data. ${ }^{8}$

Since we are engaged in capturing territorial innovation capacity in a complex way on the basis of the innovation system literature, we have to face a vital methodological problem. An important aspect of the complexly measured territorial innovation performance is the knowledge creating ability of a region which, to a great extent, depends on the presence of HEIs. This infers the contribution of HEIs to overall performance is strongly expected. Therefore, in line with the literature of regional innovation systems (Tödtling and Trippl 2005; Doloreux 2002; Malecki 1997), we distinguish three main components of the subregional innovation capacity: the knowledge-creating ability, the knowledge exploitation capacity and the innovation or "smart" infrastructure of the region.

These three basic elements of a "typical" regional innovation system served as a basis for the classification of the indicators. To define the set of indicators used in the analysis we reviewed the indicator set of several earlier measurement approaches $^{9}$ on the one hand, and other the other hand we had to consider the availability of the potential indicators on the subregional level.

Based on all this, the survey was started with 26 indicators, eight of which were classified in the subindex of knowledge creation, nine fell in the subindex of knowledge exploitation and another nine were included in the "smart" infrastructure (Table 2). The subindexes measure the performance in these three categories and serve as the basis of the Subregional Summary Innovation Index (SRSI) with an equal weight. The indicators of the Knowledge Production Index measure the ability to create new scientific and technological knowledge. The indicators of the Knowledge Exploitation Index (KEI) attempt to measure the characteristics of the innovative business sectors, while the Smart Infrastructure Index systematizes the factors that provide a background for sustaining knowledge production and exploitation.

During the calculation of the index values we built on the methodology of the European Innovation Scoreboard's Summary Innovation Index. On this basis the construction of our Subregional Summary Innovation Index is as follows:

\footnotetext{
8 The detailed results of this subregional innovation measurement exercise is available in Bajmócy and Szakálné (2009).

9 The Summary Innovation Index of the European Innovation Scoreboard (EIS 2008), the Service Sector Innovation Index of the European Trend Chart on Innovation (Kanerva et al. 2006), the EXIS Summary Index (Arundel and Hollanders 2005), the National Innovative Capacity Index of Porter and Stern (2003), the Europe Creativity Index of Florida and Tingali (2004), the RRSI Index of the European Regional Innovation Scoreboard (Hollanders 2006), the analysis of Csizmadia and Rechnitzer (2005) regarding the innovation potential of Hungarian cities.
} 
Table 2 Indicator set for measuring subregional innovation capacity

\begin{tabular}{llr}
\hline Category & Indicator \\
\hline Knowledge creation & & 1 \\
1 & Number of R\&D performing units per 100,000 inhabitants & 2 \\
2 & Total staff of R\&D units per 1,000 inhabitants & 3 \\
3 & Number of scientists with PhD per 10,000 inhabitants & 4 \\
4 & Number of teaching staff of higher education institutions & 5 \\
5 & per 1,000 inhabitants & 6 \\
6 & Investments of R\&D units per 1,000 inhabitants & 7 \\
7 & R\&D costs per 1,000 inhabitants & 8
\end{tabular}

Knowledge exploitation

\begin{tabular}{|c|c|}
\hline 1 & Export sales as a percent of total sales \\
\hline 2 & Export sales per inhabitant \\
\hline 3 & Number of foreign owned companies per 1,000 inhabitants \\
\hline 4 & $\begin{array}{l}\text { Share capital of foreign owned companies as a } \% \text { of total } \\
\text { share capital }\end{array}$ \\
\hline 5 & Incomes from intellectual properties per inhabitant \\
\hline 6 & $\begin{array}{l}\text { Percent of companies in NACE } 24 \text { and 29-34 divisions within } \\
\text { all companies (high and medium tech manufacturing) }\end{array}$ \\
\hline 7 & $\begin{array}{l}\text { Percent of companies in NACE } 64 \text { and } 72-73 \text { divisions within } \\
\text { all companies (high-tech services) }\end{array}$ \\
\hline 8 & $\begin{array}{l}\text { Percent of companies in NACE } 74 \text { division within all } \\
\text { companies (business services) }\end{array}$ \\
\hline 9 & $\begin{array}{l}\text { Number of knowledge-intensive firms with more than } 50 \\
\text { employees per } 100,000 \text { inhabitants }\end{array}$ \\
\hline \multicolumn{2}{|c|}{ Smart-infrastucture } \\
\hline 1 & Percent of employees with university or college degree \\
\hline 2 & $\begin{array}{l}\text { Percent of white collar workers in leading positions within all } \\
\text { employees }\end{array}$ \\
\hline 3 & $\begin{array}{l}\text { Number of full-time students in higher education institutions } \\
\text { per } 1,000 \text { inhabitants }\end{array}$ \\
\hline 4 & Number of ISDN lines per 1,000 inhabitants \\
\hline 5 & Broad band internet access per 1,000 inhabitants \\
\hline 6 & Registered members of public libraries per 1,000 inhabitants \\
\hline 7 & Cinema visits per 1,000 inhabitants \\
\hline 8 & Museum visitors per 1,000 inhabitants \\
\hline 9 & $\begin{array}{l}\text { Tourist arrivals in public accommodation establishments } \\
\text { per } 1,000 \text { inhabitants }\end{array}$ \\
\hline
\end{tabular}

The innovation performance refers to year 2007, however in case of certain indicators we had to consider the last available data (indicators $14-17$ refer to 2005,3 and 8 refer to 2004, and 18-19 refer to 2001). At indicators 14-16 the sector codes refer to TEÁOR'03 (NACE 3.1). The source of data: TEIR-Hungarian Spatial Development Information System, Hungarian Statistics Office (HSO) Central and Territorial Database, HSO R\&D Database, HSO Census Database, Hungarian Patent Office Pipacsweb Database and Hungarian Academy of Sciences General Assembly Database 
1. Rescaling of the values. We subtracted the indicator's minimum ${ }^{10}$ from each subregional value and divided by the difference of the maximum and minimum value. In this way all the rescaled values are between 0 and 1 .

2. Calculating the subindexes. The subindexes are calculated as the arithmetical mean of the rescaled values of the indicators in their group.

3. Calculating the SRSI. The SRSI is calculated as the unweighted arithmetical mean of the three subindexes. The SRSI and the subindex values are measured on scale therefore they are capable of being used for the comparison of the subregions. The distance of subregional innovation performance from the national average can also be interpreted in this way.

Out of the results of our innovation performance analysis we utilized the SRSI and the KEI values. The other two subindex values are heavily influenced by indicators that can directly or indirectly be linked to the presence of HEIs, therefore we could not use them in our study. SRSI is also influenced by these indicators, even though we decided to use this index as a dependent variable. In this case the overall influence of HEI-related indicators is presumably much more modest, the effects of other indicators may overcompensate it. Nevertheless these results have restricted power.

For the calculation of the KEI we did not use any HEI-related indicators, so in this case we do not have to face such a problem. The analysis of knowledge exploitation ability has basic importance in our examinations, since it may be able to transform the university outputs into increased economic performance.

The measurement of the subregional innovation performance is certainly characterized by huge weaknesses, such as its limited ability to capture the relations among the elements of the system, or the lack of innovation survey data. We still believe that at this very low level of aggregation our indexes might be able to provide a more complex picture of territorial innovation capacity than methods that equal innovation performance with one highlighted indicator.

The distorting effects of the Budapest subregion

During the analysis we inevitably had to consider that a significant proportion of Hungary's population, economic performance and research capacity is concentrated in the subregion of the capital (Budapest). The values of the Budapest subregions significantly influence the average values of the dependent variables and thus distort the results of our examinations. This effect is so significant that we had to remove the values of the Budapest subregion from the database in order to gain a more realistic picture on the remaining part of the country. Thus all our results refer to Hungary's extra-Budapest parts. We certainly removed the values of Budapest also when calculating the average values of the given indicators.

\footnotetext{
${ }^{10}$ During the calculation of the minimum and maximum value of an indicator we removed the outliers (if its distance from the national average exceeded the standard deviation for more than four times). The rescaled values of these figures are zero or one depending on the direction of deviation.
} 


\section{Results}

During the presentation of the results we follow the steps of analysis outlined in "The steps of the analysis". During the given steps we first show the results regarding the dependent variables SRSI and KEI, and then regarding the further two dependent variables. This is in line with the logic of universities' knowledge-effects, since innovation capacity (and especially the knowledge exploitation ability) can lead to the increased economic performance and incomes.

By comparing the performance of subregions with HEI (let us call them study population), and subregions without HEI (control group) we gained an overview on HEIs' effects on the dependent variables. The differences between the two groups are spectacular.

The SRSI and the KEI value of the control group (0.32 and 0.45$)$ is significantly higher than in the case of the control group (0.13 and 0.14$)$. With respect to the other two dependent variables the case seems to be more complex. Regarding the per capita GVA the study population departs from a significantly better position (well above the national average), which may be due to the size or partially the static income effects of HEIs. But the advantageous initial position did not infer a more intense growth rate. In fact the differences between the two groups decreased. ${ }^{11}$

The case is quite similar regarding the change in "tax base per tax payer", however the differences are not too sharp this time. ${ }^{12}$ The apparently higher baseyear performance may partially explain the lower growth rates in itself, but only partially, since in Hungary the territorial disparities measured at both regional and subregional level widen (Lukovics 2008). Therefore the higher base-year values do not necessarily infer the lower growth rates.

Therefore notable differences appeared between the study population and the control group. However the direction of the deviation was surprisingly opposite regarding innovation and economic performance. Nevertheless, these differences cannot be unambiguously accredited to the presence of HEIs at this level of analysis, since they may derive from many other factors.

\section{Explanatory power of the control variables}

We attempted to reveal the causes of the differences between the study population and the control group by introducing control variables. First, we had to test the explanatory power of the used control variables. We fitted linear regression models on all our dependent variables, where a relevant set of the control variables were used as independent variables (Table 3 ). ${ }^{13}$

The explanatory power of the control variables are high regarding SRSI and KEI, while moderate in case of gross tax base per tax payer and rather low in case of the

\footnotetext{
${ }^{11}$ Change in per capita GVA compared to the national average in percentage points is -14.68 in case of the study population and 7.15 in case of the control group. If we compare subregions with and without universities (instead of with and without HEIs) the values are -16.37 and 3.12 , respectively.

12 Change in gross tax base per tax payer compared to the national average in percentage point is -0.73 in case of the study population and 0.56 in case of the control group.

13 We provided detailed description of the method in "The steps of the analysis".
} 
Table 3 The explanatory power of the control variables

\begin{tabular}{|c|c|c|c|c|}
\hline & SRSI & KEI & GVA & Tax base \\
\hline \multicolumn{5}{|l|}{ Control variables } \\
\hline Number of employees & $\mathrm{x}$ & $\mathrm{x}$ & $\mathrm{x}$ & $\mathrm{x}$ \\
\hline Population of the centre of the subregion & $\mathrm{x}$ & $\mathrm{x}$ & $\mathrm{x}$ & $\mathrm{x}$ \\
\hline \multicolumn{5}{|l|}{ Percent employment in manufacturing and construction } \\
\hline Percent employment in services & & & & $\mathrm{x}$ \\
\hline Complex accessibility indicator & $\mathrm{x}$ & $\mathrm{x}$ & $\mathrm{x}$ & $\mathrm{x}$ \\
\hline Percent of incomes generated by proprietorships & & & & $\mathrm{x}$ \\
\hline Number of patents per 10,000 inhabitants & & & & $\mathrm{x}$ \\
\hline Base-year level of Gross personal tax-base per tax payer & & & & $\mathrm{x}$ \\
\hline Base-year level of Gross Value Added per capita & & & $\mathrm{x}$ & \\
\hline \multicolumn{5}{|l|}{ Model } \\
\hline \multicolumn{5}{|l|}{ Summary } \\
\hline$R$ & 0.835 & 0.735 & 0.514 & 0.654 \\
\hline$R^{2}$ & 0.697 & 0.541 & 0.264 & 0.428 \\
\hline Adjusted $R^{2}$ & 0.693 & 0.532 & 0.246 & 0.402 \\
\hline Std. error of the estimate & 0.059 & 0.078 & 63.647 & 3.620 \\
\hline Durbin-Watson & 2.112 & 2.102 & 1.950 & 2.053 \\
\hline \multicolumn{5}{|l|}{ ANOVA } \\
\hline Sum of squares & 1.297 & 1.161 & 235192.990 & 1556.537 \\
\hline$d f$ & 2 & 3 & 4 & 7 \\
\hline Mean square & 0.649 & 0.387 & 58798.247 & 222.362 \\
\hline$F$ & 188.574 & 64.013 & 14.515 & 16.966 \\
\hline Sig. & 0.000 & 0.000 & 0.000 & 0.000 \\
\hline
\end{tabular}

"x" means that the given control variable has been put into the "base model". We did not mark the Beta and $t$ values of the given indicators, nor did we analyse their partial effects due to the strong multicollinearity of the models

per capita GVA. This step of the analysis revealed which group of the control variables explains the variance of the given dependent variables the best, and how strong this explanatory power is.

We did not analyse the partial effects of the given indicators due to the strong multicollinearity of the models, but for the purpose of our study it was not necessary anyway. In the next step we attempt to control for the effects of these relevant control variables, and try to increase the explanatory power of these "base-models" by introducing the HEI-related variables.

\section{Regional effects of the Hungarian HEIs}

During this step we first analyzed the correspondence between our five HEI-related variables and the dependent variables while we controlled for the effects of the relevant control variables. We calculated partial correlations while controlling for the effects of the independent variables of the "base-models" (presented in Table 3): in 
other words the relevant set of control variables. These partial correlation results showed great differences with respect to the different dependent variables (Table 4).

Regarding the SRSI all the HEI-related variables proved to be significantly correlated while filtering the effects of the control variables. The partial correlation values are modest (rather strong in one case) and positive. Regarding the three other dependent variables none of the HEI-related indicators correlated significantly, when controlling for the variables of the base models.

On the basis of these results we attempted to increase the explanatory power of only one base model, the one that regards SRSI (Table 5). We used two methods to try to complement the base model with the HEI-related indicators. In model 1 we used the backward method of the SPSS, and thus four HEI-related indicators remained in the model. In model 2 we entered all the five HEI related indicators and the control variables of the base-model. The explanatory power of both two models is very strong, however it was already the case at the base model.

We must also consider an important limitation of the used methodology that we have earlier outlined in the methodological section. In the course of analysing the overall subregional innovation performance one of our subindexes measured the knowledge creating ability that was heavily influenced by indicators that can directly or indirectly be linked to the presence of HEIs. Therefore the correspondence between the SRSI and the presence of HEIs was strongly expected.

The results of our two-step analysis indicate the very restricted effects of HEIs in the Hungarian subregions (not counting with the Budapest subregion). Although the presence of HEIs influences the overall innovation performance of the host subregion (a result which has a limited power due to the set of indicators used), the contribution to the knowledge exploitation ability cannot be proved. Differences between the study population and the control group in this field can be explained well by the control variables, the introduction of HEI-related indicators did not provide extra explanatory power.

Table 4 Partial correlation results

\begin{tabular}{|c|c|c|c|c|c|c|c|c|}
\hline & \multicolumn{2}{|l|}{ SRSI } & \multicolumn{2}{|l|}{ KEI } & \multicolumn{2}{|l|}{ GVA } & \multicolumn{2}{|l|}{ Tax base } \\
\hline & Pearson's & Sig & Pearson's & Sig & Pearson's & Sig & Pearson's & Sig \\
\hline $\begin{array}{l}\text { Is there a HEI in the } \\
\text { subregion? }\end{array}$ & 0.302 & 0.000 & 0.098 & 0.214 & 0.062 & 0.432 & 0.159 & 0.045 \\
\hline $\begin{array}{l}\text { Is there a university in the } \\
\text { subregion? }\end{array}$ & 0.340 & 0.000 & 0.021 & 0.788 & -0.027 & 0.731 & -0.045 & 0.575 \\
\hline $\begin{array}{l}\text { Number of scientists with } \\
\text { PhD per } 10000 \text { inhabitants }\end{array}$ & 0.657 & 0.000 & 0.094 & 0.232 & 0.012 & 0.880 & 0.029 & 0.717 \\
\hline $\begin{array}{l}\text { Number of full-time students } \\
\text { in HEIs per } 1,000 \\
\text { inhabitants }\end{array}$ & 0.578 & 0.000 & 0.054 & 0.489 & 0.069 & 0.384 & 0.029 & 0.716 \\
\hline $\begin{array}{l}\text { Number of degrees awarded } \\
\text { in the fields of science, } \\
\text { engineering and informatics }\end{array}$ & 0.322 & 0.000 & 0.049 & 0.530 & 0.034 & 0.669 & 0.008 & 0.919 \\
\hline
\end{tabular}


Table 5 The explanatory power of HEI-related indicators regarding SRSI

\begin{tabular}{llcc}
\hline & Base model & Model $1^{\mathrm{a}}$ & ${\text { Model } 2^{\mathrm{b}}}^{\mathrm{a}}$ \\
\hline Model summary & & & \\
$R$ & 0.835 & 0.920 & 0.921 \\
$R^{2}$ & 0.697 & 0.847 & 0.849 \\
Adjusted $R^{2}$ & 0.693 & 0.841 & 0.842 \\
Std. error of the estimate & 0.059 & 0.042 & 0.042 \\
Durbin-Watson & 2.112 & 1.965 & 1.970 \\
ANOVA & & & \\
Sum of Squares & 1.297 & 1.576 & 1.580 \\
$d f$ & 2 & 6 & 8 \\
Mean Square & 0.649 & 0.263 & 0.198 \\
$F$ & 188.574 & 147.102 & 111.167 \\
Sig. & 0.000 & 0.000 & 0.000 \\
\hline
\end{tabular}

${ }^{a}$ Backward method. Dependent variable: SRSI. Independent variables: (1) Number of employees (2) Population of the centre of the subregion (3) Complex accessibility indicator (4) Is there a HEI in the subregion (5) Number of scientists with PhD per 10,000 inhabitants (6) Number of full-time students in HEIs per 1,000 inhabitants

b Enter method. Dependent variable: SRSI. Independent variables: the control variables of the "base model" and all the HEI-related indicators

Neither did the HEI related indicators influence the growth rate in GVA and tax base, when we considered the effects of the control variables. However these results leave the opportunity for the presence of income-effects open. Since the absolute position of the study population is significantly better with respect to both two variables, the presence of income-effects is quite probable. At the same time these effects are static, do not result in dynamic growth, or in other words HEIs are unable to be the catalysts of regional development in Hungary. ${ }^{14}$

\section{Conclusions}

In present paper we studied the link between the presence of higher education institutions and the innovation and economic performance of their host region in a transition country, Hungary. Unlike developed countries, the local innovation effects of universities are not significant in Hungary (outside Budapest), nor are the effects on the productivity of the host region's enterprises, or on the rise of local incomes.

By linking the presence of universities to the complex subregional innovation performance we found that the knowledge-producing ability did not result in increased knowledge-exploitation ability. In Hungary the university-based local economic development programmes are therefore carried out in such an

\footnotetext{
14 This does not infer the lack of HEIs contribution in all the subregions, but this potential catalytic role is far from being general.
} 
environment, where the knowledge-producing and knowledge-exploiting abilities are spatially departed. Hence the success of these programmes depends to a great extent on the endogenous development of industries that build on the local knowledge-producing capacity. Such a process is inevitably slow and ambiguous.

We showed that the differences between subregions with and without HEIs do not derive from the presence of universities, they can be well explained by other factors. HEIs' contribution is restricted to the optional presence of the incomeeffects, they are not able to boost the local economic performance or the disposable incomes of the residents.

Our results suggest that the nature and intensity of higher education institutions' regional economic and innovation contribution differ in developed and transition economies. This infers a strong need for further empirical evidences from transition countries, and calls for a cautious adaptation of university-based development tools that proved to be successful in highly developed regions.

Acknowledgments The research was supported by the Baross Gábor Innovation Analysis programme of the Hungarian National Office for Research and Technology (BAROSS-DA07-DA-ELEM-07-20080001). We are grateful for their comments on the earlier versions of this paper to Imre Lengyel, Philippe Laredo, Andreas Niederl and Siri Brorstad Borlaug.

\section{References}

Anselin L, Varga A, Ács JZ (1997) Local geographic spillovers between university research and high technology innovations. J Urban Econ 42(3):422-448

Antonelli C (2008) The new economics of the university: a knowledge governance approach. J Technol Transfer 33:1-22

Armstrong H, Taylor J (2000) Regional economics and policy, 3rd edn. Blackwell, Oxford

Arundel A, Hollanders H (2005) EXIS: an exploratory approach to innovation scoreboards. European trend chart on innovation. European Commission, Maastricht

Asheim BT, Coenen L (2005) Knowledge bases and regional innovation systems: comparing nordic clusters. Res Policy 34:1173-1190

Audretsch DB, Feldman MP (1996) R\&D spillovers and the geography of innovation and production. Am Econ Rev 86(3):630-640

Autant-Bernard C (2001) Science and knowledge flows: evidence from French case. Res Policy 30(4):1069-1078

Bajmócy Z (2006) Opportunities of university business incubation in less favoured regions of transition countries. In: 46th congress of European Regional Science Association, Volos, Greece. http://ideas.repec.org/p/wiw/wiwrsa/ersa06p190.html

Bajmócy Z, Szakálné Kanó I (2009) Measuring the innovation performance of Hungarian subregions. In: Bajmócy Z, Lengyel I (eds) Regional competitiveness, innovation and environment. JATEPress, Szeged, pp 99-121

Bercovitz J, Feldman M (2006) Entrepreneurial universities and technology transfer: a conceptual framework for understanding knowledge-based economic development. J Technol Transfer 31:175188

Bosma N, Harding R (2006) Global Entrepreneurship Monitor. GEM 2006 Summary Results. Babson College, London Business School. Babson Park, London

Buzás N (2003) Organizational elements of knowledge transfer in Hungary: towards a functional system of innovation. In Lengyel I (eds) Knowledge transfer, small and medium-sized enterprises and regional development in Hungary. JATE Press, Szeged, pp 32-46

Clarysse B, Wright M, Lockett A, van de Velde E, Vohora A (2005) Spinning out new ventures: a typology of incubation strategies from European research institutions. Res Policy 20(2):183-216 
Cooke P (2004) Regional innovation systems, an evolutionary approach. In: Cooke P, Heidenreich M, Braczyk HJ (eds) Regional innovation systems. The role of governance in a globalized world. Routledge, London, pp 1-18

Csizmadia Z, Rechnitzer J (2005) A magyar városhálózat innovációs potenciálja. In: Grósz A, Rechnitzer J (szerk.) Régiók és nagyvárosok innovációs potenciálja Magyarországon, MTA RKK, Pécs, Győr, pp 147-180

Csizmadia Z, Erdős F, Grosz A, Smahó M, Tilinger A (2008) Innováció a Nyugat-Dunántúlon, 2008. MTA RKK, Pécs, Gy

Doloreux D (2002) What should we know about regional systems of innovation. Technol Soc 24:243-263

Edquist C (2005) Systems of innovation approaches. Their emergence and characteristics. In: Edquist C (ed) Systems of innovation. Technologies, institutions and organizations. Routledge, London, pp 135

EIS (2008) European innovation scoreboard 2008. Comparative analysis of innovation performance. Inno Metrics, Bruxelles

Etzkowitz H, Leydesdorff L (2000) The dynamics of innovation: from national system and "Mode 2" to a triple helix of university-industry-government relations. Res Policy 2:109-123

Etzkowitz H, Webster A, Gebhardt C, Terra BRC (2000) The future of the university, the university of the future: evolution of ivory tower to entrepreneurial paradigm. Res Policy 2:313-330

Feldman PM (1994) The university and economic development: the case of Johns Hopkins University and Baltimore. Econ Develop Q 8(1):67-76

Florida R, Tingali I (2004) Europe in the creative age. DEMOS. http://www.demos.co.uk/ publications/creativeeurope

Goldfarb B, Henrekson M (2003) Bottom-up versus top-down policies towards the commercialization of university intellectual property. Res Policy 32:639-658

Goldstein H, Renault CS (2004) Contributions of universities to regional economic development: a quasiexperimental approach. Region Stud 38(7):733-746

HCSO (2004) A statisztikai kistérségek 2002-2003-as felülvizsgálatának összefoglaló eredményei. Munkaanyag. Központi Statisztikai Hivatal (Hungarian Central Statistics Office), Budapest

Hollanders H (2006) European regional innovation scoreboard. European Trend Chart on Innovation, Maastricht

Inzelt A (2004) The evolution of university, industry, government relationships during the transition. Res Policy 33(6-7):975-995

Inzelt A, Szerb L (2003) Az innovációs aktivitás vizsgálata ökonometriai módszerekkel. Közgazdasági Szemle 50(11):1002-1021

Kanerva M, Hollanders H, Arundel A (2006) Can we measure and compare innovation in services. 2006 Trend Chart Report. European trend chart on innovation, Luxemburg

Lengyel I (2009) Knowledge-based local economic development for enhancing competitiveness in lagging areas of Europe: the case of the University of Szeged. In Varga A (ed) Universities, knowledge transfer and regional development. Geography, Entrepreneurship and Policy. Edward Elgar, Cheltenhem, pp 321-349

Lengyel B, Cadil V (2009) Innovation policy challenges in transition countries: foreign business R\&D in the Czech Republic and Hungary. Trans Stud Rev 16:174-188

Lukovics M (2008) Measuring regional disparities: evidence from Hungarian sub-regions. In: Paper presented at the "Culture, cohesion and competitiveness: regional perspectives" 48th congress of the European Regional Science Association, Liverpool, UK

Lundval BA (eds) (1992) National systems of innovation. Towards a theory of innovation and interactive learning. Pinter, London

Lundvall BA, Johnson B, Andersen ES, Dalum B (2002) National systems of production, innovation and competence building. Res Policy 31:213-231

Malecki EJ (1997) Technology and economic development: the dynamics of local, regional and national competitiveness. Longman, Edinburgh

Morgan B (2002) Higher education and regional economic development in Wales: an opportunity for demonstrating the efficacy of devolution in economic development. Region Stud 36(1):65-73

Nelson RR (eds) (1993) National innovation systems. A comparative analysis. Oxford University Press, New York

Nelson RR (1995) Recent evolutionary theorizing about economic change. J Econ Lit 33(3):48-90

Porter ME, Stern S (2003) The impact of location on global innovation: findings from the national innovative capacity index. The Global Competitiveness Report 2002-2003, WEF, pp 227-252 
Tödtling F, Trippl M (2005) One size fits all? Towards a differentiated regional innovation policy approach. Res Policy 34:1203-1209

Varga A (1998) University research and regional innovation: a spatial econometric analysis of academic technology transfers. Kluwer, Boston

Varga A (2004) Az egyetemi kutatások regionális gazdasági hatásai a nemzetközi szakirodalom tükrében. Közgazdasági Szemle 51(3):259-275

Varga A (2009) Térszerkezet és gazdasági növekedés. Akadémiai Kiadó, Budapest 